\title{
Concentrations of antimony in infants dying from SIDS and infants dying from other causes
}

A Cullen, B Kiberd, D Devaney, J Gillan, P Kelehan, T G Matthews, P Mayne, N Murphy, M O'Regan, W Shannon, L Thornton

\section{Objectives}

Objectives-Raised concentrations of antimony have been found in infants dying of sudden infant death syndrome (SIDS). The presumed source of this antimony is toxic gases generated from fire retardants that are present in cot mattresses. The aim of this study was to determine the role of antimony in SIDS.

Design-Samples of liver, brain, serum, and urine were collected from all patients dying from SIDS and a group of aged

Department of Children's Hospita D Devaney

P Mayne

National Sudden Infant Death Register, The Irish Sudden Infant Death Register, Georges Hall, Temple Street, Dublin 1, Republic of Ireland B Kiberd

Department of Pathology, The Rotunda, Dublin 1, Republic of Ireland J Gillan

Department of Pathology, National Maternity Hospital, Holles Street, Dublin 2, Republic of Ireland P Kelehan

Department of Statistics, Trinity College, Dublin 2, Republic of Ireland M O'Regan

Department of General Practice, Royal College of Surgeons, Lower Stephen Street, Dublin 2, Republic of Ireland W Shannon

Department of Public Health, Baggot Street Hospital, Dublin 4, Republic of Ireland L Thornton

Correspondence to: Professor Matthews
Setting-Nationwide study in Ireland. Subjects-52 infants dying from SIDS and 19 control infants aged $>7$ days and $<1$ year.

Results-The median concentration of antimony in the liver and brain of infants dying of SIDS was $<1 \mathrm{ng} / \mathrm{g}$, with no difference detected between the infants dying from SIDS and the control infants. The range of antimony in the serum of infants dying of SIDS was 0.09-0.71 $\mu \mathrm{g}$ / litre (median, 0.26). Although no difference was found between infants dying from SIDS and control infants, SIDS infants were found to have higher concentrations when compared with healthy infants in the 1st year of life, probably as a result of release of antimony into serum after death. Urine antimony concentrations in infants dying from SIDS were $<3.91 \mathrm{ng} / \mathrm{mg}$ (corrected for creatinine) infants and healthy infants. Conclusion-There is no evidence to support a causal role for antimony in SIDS. (Arch Dis Child 2000;82:244-247)

Keywords: sudden infant death syndrome; antimony

The sudden infant death syndrome (SIDS) is defined as any death occurring in an infant or young child that is unexpected by history and in which a thorough postmortem examination fails to demonstrate an adequate cause of death. ${ }^{1}$ It was proposed recently that microbial arsenic, and phosphorus based additives, which were used as fire retardants in cot mattresses, could cause SIDS. ${ }^{23}$ Further evidence for this theory was cited when investigators for the Cook Report (Central Television Programme 1994) confirmed detectable amounts of antimony in liver samples of 22 of 41 infants dying from SIDS but only one of 15 and similar to values found both in control generation of toxic gases from antimony, control infants. ${ }^{4}$ In addition, serum samples from 19 of 39 infants dying from SIDS but only two of 13 control infants had detectable amounts of antimony. ${ }^{4}$ Although subsequent studies have been unable to confirm the evolution of toxic gases from cot mattresses, ${ }^{5-8}$ there has been conflicting information in the literature regarding the concentrations of antimony in liver samples of infants dying from SIDS. ${ }^{9}{ }^{10}$ The purpose of our study was to clarify the role, if any, of antimony in SIDS.

\section{Methods}

All sudden unexpected deaths in infants and young children occurring in Ireland are reported to the Irish Sudden Infant Death Association's national sudden infant death register within 48 hours of the time of death. Death certificates, issued by the coroner, are subsequently forwarded to the register, ensuring complete ascertainment of all cases. For our study, control infants were also enrolled. A control infant was defined as any infant dying from any cause other than SIDS (as determined by postmortem examination and death certification) in the 1 st year of life. Enrollment began on 1 January 1995 and ended on 31 January 1997. Infants less than 7 days or over 1 year of age were excluded.

For each case and control, postmortem samples of liver, brain, serum, and urine were obtained. To avoid the possibility of contamination and to ensure that results from different institutions were uniformly comparable, special kits were provided that included containers that had been tested and found to be antimony free. Samples of fresh liver and brain, approximately $1 \mathrm{~cm}^{3}$, were collected and placed into $30 \mathrm{ml}$ screw capped polystyrene containers (LIP, Shipley, West Yorkshire, UK). All available urine was collected and placed into similar containers. Blood was collected either peripherally or centrally and placed into $10 \mathrm{ml}$ preservative free, polypropylene tubes (Sarstedt, Nürnbrecht, Germany), which had been washed with $10 \%$ hydrochloric acid before use. Samples were spun immediately and the serum transferred into similarly prepared $3.5 \mathrm{ml}$ tubes. Samples were kept frozen at $-20^{\circ} \mathrm{C}$ until transported on dry ice to the SIDS tissue bank within 48 hours of the postmortem examination. The samples were stored at $-70^{\circ} \mathrm{C}$ until analysed.

All samples were analysed by inductively coupled plasma mass spectrometry (ICP-MS), a method that has been shown to be of sufficient sensitivity to measure physiological concentrations of antimony (HT Delves, 
Clinical Biochemistry, University of Southampton; TBD Lyon and GS Fell, Clinical Biochemistry, Royal Infirmary, Glasgow). ${ }^{11}$ The limit of detection of the method was $1 \mathrm{ng} / \mathrm{g}$ wet tissue weight for liver and brain and $0.01 \mu \mathrm{g} /$ litre for serum and urine. All specimens were numerically coded, ensuring that the laboratory performing the analysis was unaware of whether the specimen was from an infant dying from SIDS or a control infant.

Because the original Cook Report had analysed serum, it was decided also to measure antimony concentrations in serum so that results could be compared. However, antimony is known to associate preferentially with red blood cells. ${ }^{12}{ }^{13}$ Therefore, it was possible that a delay in the collection of blood or in the separation of red blood cells from the serum at the time of the postmortem examination could result in a falsely raised serum antimony concentration. Because this could complicate the interpretation of antimony concentrations in SIDS, an assessment of the magnitude of such an effect was undertaken. Blood was collected from six adults and divided into seven aliquots of $5 \mathrm{ml}$ each. Five samples were left unseparated at room temperature for $0,2,4,8$, and 24 hours, respectively, before being spun and separated into serum and red blood cell components. The final two samples were spun and separated soon after collection. The red blood cell casts obtained from these latter two samples were frozen for 30 minutes and rapidly thawed to ensure complete haemolysis of the red cells present. By adding $5 \mu \mathrm{l}$ of the resultant solution to one sample and $25 \mu \mathrm{l}$ of the solution to the other sample, it was possible to produce two samples, one of which appeared to be barely haemolysed to the naked eye and the other that appeared to be grossly haemolysed. All samples were then analysed for antimony and the results are outlined in fig 1 . It was shown that the antimony concentration in the serum gradually rose over a period of 24 hours. Haemolysis also caused a rise in the serum concentration, although it was not possible to quantify its contribution other than to say that it was associated.

\section{Results}

During the study period, there were 90 cases of sudden unexpected deaths reported to the register. Of these, 82 were classified as SIDS after the postmortem examination. Excluding infants less than 7 days and over 1 year, 75 infants were eligible for the study and samples were obtained from $52(69 \%)$ of them. In

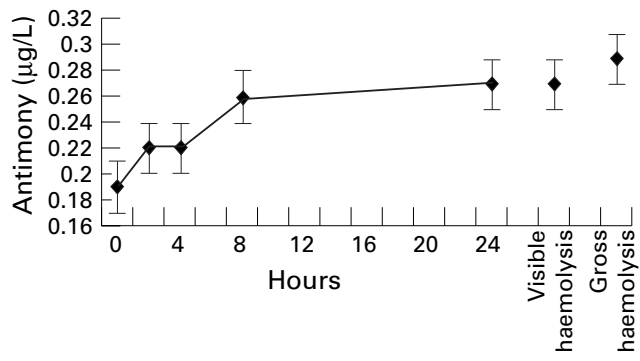

Figure 1 Effect of delayed separation of red blood cells and haemolysis on the serum antimony concentration.
Table 1 Cause of death of control infants

\begin{tabular}{lc}
\hline Category of death & $n$ \\
\hline Congenital causes & 7 \\
Perinatal causes & 3 \\
Infective causes & 6 \\
Other causes & 3 \\
Total & 19 \\
\hline
\end{tabular}

addition, samples were obtained from 19 control infants. Table 1 outlines the cause of death of the 19 infants. The mean age of death for the infants dying from SIDS was 15 weeks (SD, 10; range, 2-41) and for the control infants it was 17 weeks (SD, 14; range, 1-46).

\section{ANTIMONY IN LIVER}

Liver samples were obtained from 51 of the 52 infants dying from SIDS and 19 controls. Results were available from all SIDS samples but only 18 of the control samples because one of the latter samples was destroyed during the digestion process. A total of $36(72 \%)$ of the 51 infants dying from SIDS and $12(66 \%)$ of the 18 control infants had antimony concentrations in their livers below the detection limit of the method ( $<1 \mathrm{ng} / \mathrm{g}$ wet tissue weight). For the purpose of calculations, these were assigned a value equivalent to the detection limit of the method $(0.99 \mathrm{ng} / \mathrm{g})$. This would, if anything, overestimate the amount of antimony in the specimen, but was felt to be more appropriate when issues of safety were being questioned. One infant dying from SIDS had an antimony concentration of $51 \mathrm{ng} / \mathrm{g}$, which was confirmed on retesting the same sample. Table 2 outlines the concentrations of antimony in the liver of infants at postmortem examination. The median concentration of antimony in liver was $<1 \mathrm{ng} / \mathrm{g}$ both for infants dying from SIDS and for control infants. There was no difference in antimony concentrations between the two groups (Mann Whitney $U$ test, $p=0.8$ ), irrespective of the inclusion of the outlier value.

\section{ANTIMONY IN BRAIN}

Brain samples were obtained from 42 infants dying from SIDS and 11 control infants (table 3). In all, 36 (86\%) of the 42 infants dying from SIDS and $10(91 \%)$ of the 11 control infants had antimony concentrations that were below the detection limit of the method and, for the purpose of analysis, these samples were also assigned the value of $0.99 \mathrm{ng} / \mathrm{g}$. The median concentration of antimony in brain was $<1 \mathrm{ng} /$ $\mathrm{g}$ both for infants dying from SIDS and for

Table 2 Antimony concentrations in liver tissue

\begin{tabular}{lcl}
\hline $\begin{array}{l}\text { Antinomy concentration } \\
\text { (ng/g wet weight) }\end{array}$ & $\begin{array}{l}\text { Infants dying } \\
\text { from SIDS }\end{array}$ & Controls \\
\hline $0-0.99$ & $36(72 \%)$ & $12(66 \%)$ \\
$1-1.99$ & $5(10 \%)$ & $2(11 \%)$ \\
$2-2.99$ & $6(12 \%)$ & $2(11 \%)$ \\
$3-3.99$ & $1(2 \%)$ & $1(6 \%)$ \\
$\geqslant 4$ & $3(4 \%)^{\star}$ & $1(6 \%) \dagger$ \\
Total & $51(100 \%)$ & $18(100 \%)$ \\
\hline${ }^{\star}$ Includes one infant dying from SIDS with an antimony \\
concentration of $51 \mathrm{ng} / \mathrm{g}$ and two with concentrations of $4 \mathrm{ng} / \mathrm{g}$ \\
each. \\
†Includes one control infant with a concentration of $4 \mathrm{ng} / \mathrm{g}$.
\end{tabular}


Table 3 Antimony concentrations in brain tissue

\begin{tabular}{lll}
\hline $\begin{array}{l}\text { Antimony concentration } \\
\text { (ng/g wet weight) }\end{array}$ & $\begin{array}{l}\text { Infants dying } \\
\text { from SIDS }\end{array}$ & Controls \\
\hline $0-0.99$ & $36(86 \%)$ & $10(91 \%)$ \\
$1-1.99$ & $3(7 \%)$ & $1(9 \%)$ \\
2 to $\leqslant 3$ & $3(7 \%)$ & $0(0 \%)$ \\
Total & $42(100 \%)$ & $11(100 \%)$ \\
\hline
\end{tabular}

control infants. There was no difference between the two groups (Mann Whitney U test, $\mathrm{p}=0.36$ ).

ANTIMONY IN SERUM

The reference range for antimony in the serum of infants in the 1st year of life has been previously established as $0.09-0.25 \mu \mathrm{g} /$ litre, confirming the presence of negligible amounts of this metal in the serum of healthy infants. ${ }^{14}$

Serum samples from 30 infants dying from SIDS and seven control infants were analysed. None of the samples was noted to be haemolysed. The range of antimony in the serum of infants dying from SIDS was $0.09-0.71 \mu \mathrm{g} /$ litre, with a median of $0.26 \mu \mathrm{g} /$ litre. The range for the control cases was 0.08 $0.3 \mu \mathrm{g} /$ litre, with a median of $0.17 \mu \mathrm{g} /$ litre after excluding one sample with a concentration of $7.2 \mu \mathrm{g} /$ litre, which was confirmed on retesting the sample (including this outlier, the median was $0.19 \mu \mathrm{g} /$ litre). There was no significant difference between the median values of the cases and the controls (Mann Whitney $\mathrm{U}$ test, $\mathrm{p}=0.49$ ), even with the inclusion of the outlier.

Figure 2 compares the serum values of the cases and the controls (excluding the one outlier) with the serum values obtained from 187 randomly selected infants in the 1 st year of life (aged 28 weeks; SD, 16; range, 2-52). These infants formed part of a study, the details of which have been outlined in an earlier report. ${ }^{14}$ It was noted that five (17\%) of the 30 SIDS values were higher than the upper limit of the control values $(0.3 \mu \mathrm{g} /$ litre after excluding the outlier result) and that $15(50 \%)$ of the SIDS values and one $(17 \%)$ of the six control values were above the upper limit of the previously established reference range for this random population $(0.25 \mu \mathrm{g} /$ litre $)$. The three groups were compared using an ANOVA test (analysis of variance). Overall there was a difference between the three groups ( $f=15.76$; degrees of freedom $(\mathrm{df})=2,220 ; \mathrm{p}<0.001)$. Although the control group did not differ from the

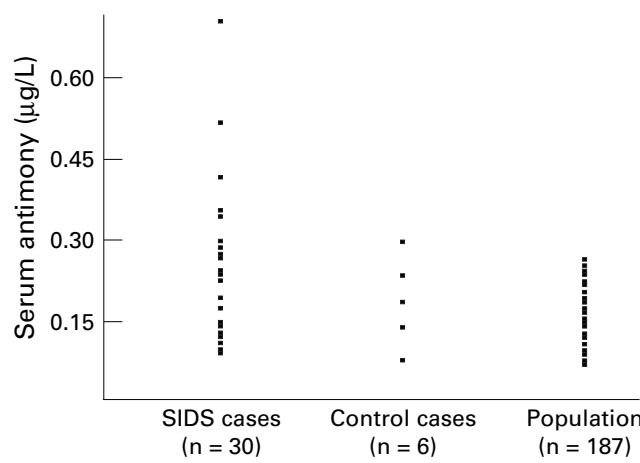

Figure 2 Comparison of the antimony concentration in serum between the three populations.

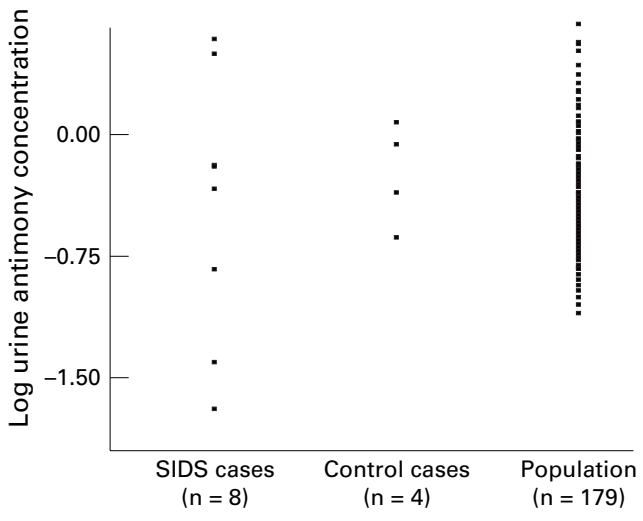

Figure 3 Comparison of the log antimony concentration in urine between the three populations.

random population $(\mathrm{p}=0.71)$, the SIDS group differed both from the control group $(p<0.01)$ and from the random population $(p<0.001)$. Inclusion of the outlier in the control group did not affect these results.

There was no correlation between the concentrations of antimony in the serum of infants dying from SIDS and the amounts detected in liver and brain. Of the 15 infants dying from SIDS in whom serum antimony concentrations exceeded the expected range for infants in the 1 st year of life, 14 had undetectable antimony in the liver and 14 had concentrations of less than $2 \mathrm{ng} / \mathrm{g}$ in the brain.

ANTIMONY IN URINE

Infants in the 1st year of life were found to have a urinary antimony concentration corrected for creatinine $(\mathrm{Cr})$ of less than $2.6 \mathrm{ng} / \mathrm{mg} \mathrm{Cr} .{ }^{14} \mathrm{In}$ our study, urine samples were available from only eight infants dying from SIDS and four control infants. In one of the infants dying from SIDS, antimony was not detected in the urine and the range for the remaining seven specimens was from $0.02-3.91 \mathrm{ng} / \mathrm{mg} \mathrm{Cr}$ (median, 0.56). The range for the four control cases was $0.24-1.21 \mathrm{ng} / \mathrm{mg} \mathrm{Cr}$ (median, 0.67). Figure 3 compares the log antimony concentrations in the urine between the three populations (infants dying from SIDS, control infants, and population of infants in the 1 st year of life). Although two (25\%) of the eight SIDS specimens and none of the control specimens exceeded the upper 97.5th centile for urinary antimony in the normal population, comparison of the three groups using an ANOVA test revealed no significant difference between the groups $(f=0.55 ; d f=2,188 ; p=0.58)$. The two infants dying from SIDS with raised concentrations of antimony in the urine had undetectable amounts in the liver and brain.

\section{Discussion}

Our study confirms the presence of negligible amounts of antimony in the liver and brain of infants dying from SIDS and infants dying from other causes. We found concentrations in the liver to be even lower (although of the same magnitude) than the values found in previous studies by Taylor et al (infants dying from SIDS, $7.11 \mathrm{ng} / \mathrm{g}$; controls, 0.5), ${ }^{9}$ Howatson et al (infants dying from SIDS, $6 \mathrm{ng} / \mathrm{g}$; controls, 
7), ${ }^{10}$ and Delves et al (controls, $2 \mathrm{ng} / \mathrm{g}$; range, $0.7-37) .{ }^{11}$ Concentrations in the liver were also considerably lower than those reported for adults. ${ }^{15-19}$ Although there is no published information on antimony concentrations in paediatric brain tissue for comparison, one study in adults estimated it to be in the region of $10 \mathrm{ng} / \mathrm{g}$ wet weight and to be of the same order of magnitude as concentrations found in the liver and kidney. ${ }^{19}$ Our study would suggest that the concentrations in infants are even lower.

Although $17 \%$ of the infants dying from SIDS had serum antimony concentrations greater than the upper limit of the control infants, the small sample size of the control group made it difficult to determine whether a difference truly did exist. However, when compared with a group of randomly selected infants in the 1 st year of life, $50 \%$ of the infants dying from SIDS were found to have serum antimony concentrations that exceeded the upper limit of normal for these infants. Work carried out to assess the effect of delayed separation of red blood cells and haemolysis of red blood cells on the serum antimony concentration in adults suggests that the difference in SIDS postmortem results might be the result of the release of antimony from red blood cells into the serum after death. The fact that only one of the six control specimens, as opposed to 15 of the SIDS specimens, was above the expected range might be a reflection of the small numbers sampled, but could also be related to the timing of the postmortem examination. Critically ill infants frequently die in hospitals or tertiary referral centres, where postmortem examinations may happen more expediently, or where blood is drawn from the infant immediately after death. Infants dying from SIDS may be dead for a number of hours before discovery and may not undergo a postmortem examination until the next day. It is conceivable that these differences in sample collection could account for the higher amounts of antimony in the serum of infants dying from SIDS as opposed to control infants. Unfortunately, accurate information regarding the timing of death and the timing of blood drawing and subsequent separation of red blood cells was not available and so no definitive conclusion can be drawn.

None of the infants dying from SIDS with serum antimony concentrations that exceeded the range for infants in the 1st year of life were found to have raised concentrations of antimony in liver or brain. From our knowledge of the metabolism of antimony in the human body, it has been shown that repeated doses of antimony result in the accumulation in the liver, independent of the concentration in red blood cells. ${ }^{1320}$ Therefore, it is unlikely that concentrations in serum would be raised independently of the liver. A possible exception to this would be in the situation of acute poison- ing, although it would be hard to imagine that serum concentrations of $<1 \mu \mathrm{g} /$ litre could result in infant deaths when values of $8-10 \mathrm{mg} /$ litre have been reported in adults taking antimonial drugs without any clinical effect. ${ }^{21}{ }^{22}$

In conclusion, this study does not support the suggestion that antimony plays a causal role in death from SIDS. The importance of accurate methodologies, stringent collection protocols, and an appreciation of differences in sample handling cannot be over emphasised if one is to avoid erroneous results.

Thanks to the scientific advisory committee of the national sudden infant death register: D Devaney, J Gillan, M Grant, N Harmey, P Kelehan, B Kiberd, S Lynch, T Matthews, P Mayne, M McDonnell, M O'Doibhlinn, M O'Regan, S Quirke, W Shannon, L Thornton. Thanks also to $\mathrm{P}$ Leahy for his assistance.

1 Bergman AB, Beckwith JB, Ray CG. Proceedings of the second international conference on causes of sudden infant death syndrome in infants. Seattle: University of Washington Press, 1970:17-18

2 Richardson BA. Cot mattress biodeterioration and SIDS. Lancet 1990;335:670.

3 Richardson BA. Sudden infant death syndrome: a possible primary cause. $\mathcal{F}$ Forensic Sci Soc 1994;34:199-204.

4 Fleming PJ, Cooke M, Chantler SM, Golding J. Fire retardFleming PJ, Cooke $M$, Chantler SM, Golding J. Fire retard-
ants, biocides, plasticisers and sudden infant deaths. BMF 1994;309:1594-5.

5 Sudden infant death syndrome (SIDS). Report of the expert working group enquiring into the hypothesis that toxic gases evolved from chemicals in cot mattresses covers and cot mattresses are a cause of SIDS. London: HMSO, 1991.

6 Gates PN, Prindham JB, Webber JA. Sudden infant death syndrome and volatile antimony compounds. Lancet 1995; 345:386-7.

7 Thompson M, Faull JL. Do microbiota cause emission of stibine from cot mattresses. Lancet 1995;346:1557-8.

8 Warnock DW, Delves HT, Campbell CK, et al. Toxic gas generation from plastic mattresses and sudden infant death syndrome. Lancet 1995;346:1512-20.

9 Taylor A. Antimony, cot mattresses and SIDS. Lancet 1996; 347:616.

10 Howatson AG, Patrick WJA, Fell GS, Lyon TBD, Gibson AAM. Cot mattresses and sudden infant death syndrome. Lancet 1995;345:1044-5.

11 Delves HT, Sieniawska CS, Fell GS, et al. Determination of antimony in urine, blood, serum and in liver and lung antimony in urine, blood, serum and in liver and lung

12 Windship KA. Toxicity of antimony and its compounds. Adv Drug React Acute Poisoning Rev 1987;2:67-90.

13 Edel J, Marafante E, Sabbioni E, Manzo L. Metabolic behaviour of inorganic forms of antimony in the rat. In: International conference on heavy metals in the environment, Heidelberg. Edinburgh: CEP Consultants Ltd, 1983:574-7.

14 Cullen A, Kiberd B, Matthews T, Mayne P, Delves HT, O'Regan M. Antimony in blood and urine of infants. $\mathcal{F}$ Clin Pathol 1998;51:238-40.

15 Kennedy JH. Analysis of diseased and normal lung tissue for race antimony content by neutron activation analysis. Am $\mathcal{F}$ Med Sci 1966;251:37-9.

16 Nixon GS, Livingston HD, Smith H. Estimation of antimony in human enamel by activation analysis. Caries Res 1967;1:327-32.

17 Schicha H, Kasperek K, Feinendegen LE, Siller V, Klein HJ. Inhomogeneous but partly parallel distribution for cobalt, iron, selenium, zinc and antimony in different regions of iver, lung, kidney, heart and aorta, measured by neutron activation analysis [in German]. Beitr Pathol 1972;146:5562 .

18 Sumino K, Hayakawa K, Shibata T, Kitamura S. Heavy metals in normal Japanese tissues. Arch Environ Health 1975;30:487-94.

19 Yukawa M, Amano K, Suzuki-Yasumoto $M$, Terai $M$. Distribution of trace elements in the human body determined by neutron activation analysis. Arch Environ Health 1980;35:36-44.

20 Elinder CG, Friberg L. Antimony. In: Friberg L, Norberg F, Vouk VB, eds. The handbook on the toxicology of metals, 2nd ed. Amsterdam: Elsevier Science Publishers, 1986:26-42.

21 Chulay JD, Fleckenstein L, Smith DH. Pharmacokinetics of antimony during treatment of visceral leishmaniasis with antimony during treatment of visceral leishmaniasis with sodium stibogluconate or meglum
Soc Trop Med Hyg 1988;82:69-72.

22 Jaser MA, El-Yazigi A, Croft SL. Pharmacokinetics of antimony in patients treated with sodium stibogluconate for cutaneous leishmaniasis. Pharm Res 1995;12:113-16. 